\title{
Sistem Informasi Rekam Medis Berbasis Web Pada Klinik Risa Rafana Menggunakan Metodologi Extreme Programming
}

\author{
Jihadul Akbar ${ }^{*}$, Ainul Yaqin ${ }^{2}$ \\ ${ }^{1}$ Magister Teknik Informatika, Universitas Amikom Yogyakarta \\ 2Fakultas IImu Komputer, Universitas Amikom Yogyakarta \\ *jihadul4kbar@gmail.com
}

\begin{abstract}
Abstrak
Klinik Risa Rafana adalah klinik yang beralamatkan di Wage Batujai Praya Barat, Kabupaten Lombok Tengah Provinsi Nusa Tenggara Barat. Klinik Risa Rafana mengalami kendala dalam mengolah data rekam medik karena sistem yang ada tidak dapat mendata pasien secara sistematis sehingga petugas klinik kesulitan mencari data pasien yang sudah ada. Metode pengembangan Sistem Informasi Rekam Medik Klinik Risa Rafana ini menggunakan metodologi Extreme Programming. Metode ini mengutamakan klien sebagai sebagai narasumber yang mengerti tentang sistem yang akan dibuat, dari klien tersebut diperoleh user story. Tahapan - tahapan dalam metode ini antara lain planning, design, coding dan testing. Sistem informasi ini didesain dengan konsep UML (Unified Modelling Language) dan dikembangkan menggunakan Framework PHP (Hypertext Preprocessor) yakni Codeigniter yang berbasis web. Pengolah databasenya menggunakan MySQL. Sistem informasi ini dapat mengolah data pasien, dokter, dokter spesialis, laboratorium, rontgen, obat, sehingga dapat membuat informasi rekam medik dan membuat laporan perawatan pasien, laporan pemeriksaan laboratorium, laporan pemeriksaan rontgen, laporan resep obat, laporan penjualan obat yang telah diberikan pada pasien sehingga memudahkan dalam mendiagnosa penyakit yang diderita oleh pasien
\end{abstract}

Kata kunci: Rekam Medis, Codelgniter, Extreme Programming, Sistem Informasi, UML

\begin{abstract}
Risa Rafana is a clinic that located at Wage Batujai West Praya, Central Lombok, West Nusa Tenggara Province. Risa Rafana clinic has problems in medical records processing because the existing system could not systematically assess patient, so the clinicians had trouble for finding the data of patients when had been in manual system. The is development method that was used is Extreme Programming methodology. The method prioritizing of clients as a resource person who understand the system that will be created, from the client itself acquired user story. The Stages that will be created such as planning, design, coding and testing. The information system is designed by concept of UML (Unified Modeling Language) and developed using Framework PHP (Hypertext Preprocessor), which is a web-based Codelgniter. The processing of database by MySQL. The information system could process data of patients, doctors, specialists, labs, rontgen, medications, so it could make medical records information and made report of patient's surgery, reporting of laboratory check, reporting of medicine prescription, reporting of drug selling that has been given to patients, so it made easier to diagnose the disease..
\end{abstract}

Keywords: Medical Records, Codelgniter, Extreme Programming, Information Systems, UML

\section{Pendahuluan}

Kemajuan teknologi saat ini telah mengalami perkembangan yang sangat pesat. Komputer merupakan kemajuan teknologi yang

memudahkan dalam proses pengolahan dan penyajian data sehingga menghasilkan informasi 
yang diperlukan dan dipergunakan dalam berbagai macam keperluan. Sistem informasi rekam medik mengolah data pasien, data diagnosa pasien, data obat, data dokter, dan data perawatan. Data yang diolah tersebut menghasilkan laporan pasien, dokter, diagnosa pasien, dan laporan diagnosa penyakit yang banyak diderita pasien dalam jangka waktu tertentu. Dari laporan - laporan tersebut menghasilkan informasi yang dapat dipergunakan oleh dokter dan direktur untuk mengambil keputusan. Klinik Risa Rafana adalah klinik yang beralamatkan di Wage Batujai Praya Barat, Kabupaten Lombok Tengah Provinsi Nusa Tenggara Barat. Klinik Risa Rafana mengalami kendala dalam mengolah data rekam medis, karena sistem yang ada tidak dapat mendata pasien secara sistematis sehingga petugas klinik kesulitan mencari data pasien yang sudah ada. Pengelolaan data rekam medis pada Klinik Risa Rafana saat ini memerlukan aplikasi pendukung untuk memperoleh sistem informasi rekam medis yang berkesinambungan antara sistem manual dan sistem komputerisasi.

\section{Tinjauan Pustaka}

\subsection{Penelitian Terkait}

Herlambang Brawijaya alam penelitian tersebut menggunakan metode Waterfall untuk merancang sistem, serta sistem yang dihasilkan dapat mencetak hasil rekam medis dan dokter dapat melihat perkembangan pasien [1]. Tiara Handayani menggunakan metode Systems Development Life Cycle dalam proses pengembangannya. Sistem yang dibuat dapat mencatat pasien rawat inap, data dokter, data rungan, kode prosedur ICD 9 dan pencarian diagnosa ICD 10 dan dapat mencetak laporan dari hasil input tersebut [2]. Johni S Pasaribu dalam penelitiannya metode Rational Unified Process (RUP) Rational sistem yang dihasilkan dapat mempermudah dalam mengelola data dokter, pasien, obat, stok obat, transaksi dan mencetak kartu pasien [3]. Dahlan Susilo dalam penelitiannya menggunakan bahasa pemrograman Visual Basic serta Microsoft Access sebagai pengolah databasenya. Penelitian ini menghasilkan aplikasi yang dapat menginputkan data pasien, data obat, data dokter, dan data pemeriksaan pasien, serta laporan medis [4]. Mudma'inah dalam penelitiannya, menggunakan analisis PIECES (Performance, Information, Economy, Control, Efficiency, Service) dengan bahasa pemrograman PHP (Hypertext Preprocessor) dan MySQL sebagai pengolah databasenya. Metode pengujian yang digunakan untuk menguji sistem yakni Black Box Testing dan White Box Testing [5]. Yuyun Puspitasari menggunakan bahasa pemrograman PHP dan MySQL sebagai pengolah databasenya. Sistem ini hanya mengolah data rekam medis pasien rawat jalan 
[6]. Dari penelitian terkait tentang sistem informasi rekam medis sudah menggunakan bahasa pemrograman PHP dan MySQL. Dalam penelitian yang diangkat oleh penulis akan menggunakan Framework PHP yakni Codelgniter dan MySQL sebagai pengolah database. Metode yang akan digunakan dalam penelitian ini yakni Extreme Programming $(X P)$.

\subsection{Landasan Teori}

\section{Sistem Informasi}

Sistem informasi adalah suatu sistem didalam suatu organisasi yang mempertemukan kebutuhan pengolahan transaksi harian yang mendukung fungsi organisasi yang bersifat manajerial dalam kegiatan strategis dari suatu organisasi untuk dapat menyediakan kepada pihak luar dengan laporan-laporan yang diperlukan.

\section{Klinik}

Klinik merupakan fasilitas pelayanan kesehatan yang menyelenggarakan pelayanan kesehatan perorangan yang menyediakan pelayanan medis dasar atau spesialistik [7].

\section{Rekam Medik}

Rekam medis dalah berkas yang berisikan catatan dan dokumen tentang identitas pasien, pemeriksaan, pengobatan, tindakan, dan pelayanan yang telah diberikan kepada pasien [8].

\section{XAMPP}

XAMPP adalah perangkat lunak bebas, yang mendukung banyak sistem operasi, merupakan kompilasi dari beberapa program. Fungsi dari XAMPP adalah sebagai server yang berdiri sendiri (localhost), terdiri atas program Apache HTTP Server, MySQL database, penerjemah bahasa yang ditulis dengan bahasa pemrograman PHP dan Perl [9].

\section{Framework Codelngiter}

Framework secara sederhana dapat diartikan kumpulan dari fungsi-fungsi / prosedur - prosedur dan class-class untuk tujuan tertentu yang sudah siap digunakan sehingga lebih mempermudah dan mempercepat pekerjaan seorang programmer, tanpa harus membuat fungsi atau class dari awal. Codeigniter adalah aplikasi open source yang berupa framework dengan model MVC (Model, View, Controller) untuk membangun website dinamis dengan menggunakan PHP [10].

\section{HTML (Hyper Text Markup Language)}

HTML adalah sebuah bahasa yang digunakan untuk membuat sebuah halaman web, menampilkan berbagai informasi di dalam sebuah penjelajah web internet yang ditulis dalam berkas format ASCII (American Standard Code for Information Interchange) agar dapat menghasilkan tampilan yang terintegrasi [11]. 


\section{Cascading Style Sheet (CSS)}

CSS digunakan untuk mendefinisikan gaya konstruksi tulisan, warna, dan posisi, yang digunakan untuk menggambarkan bagaimana informasi pada halaman web diformat dan ditampilkan [12].

\section{Metodologi Extreme Programming (XP)}

XP mengadopsi pendekatan agile untuk pengembangan perangkat lunak yang diasumsikan dapat membantu meningkatkan efisiensi dan fleksibilitas dari sebuah proyek pengembangan perangkat lunak dengan mengkombinasikan berbagai ide sederhana [13][14][15]. XP juga memiliki nilai-nilai mendasar yang harus diperhatikan, yaitu:

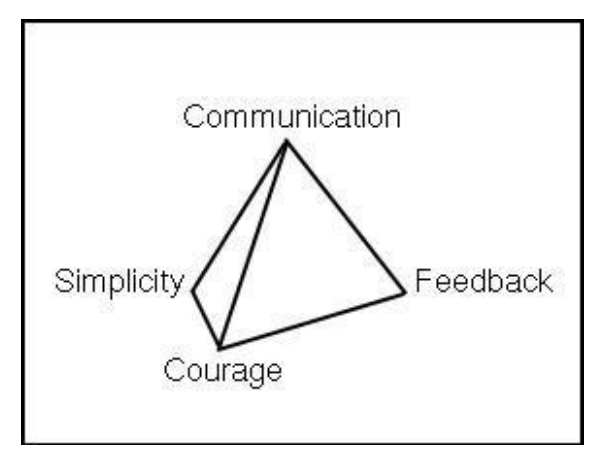

Gambar 1 Nilai dasar XP

\section{a. Communication (Komunikasi)}

$X P$ berfokus bagaimana cara agar hubungan komunikasi antar anggota tim terjalin dengan baik. Setiap anggota tim harus bisa saling pengertian dan berbagi pengetahuan serta keterampilan mengenai pengembangan perangkat lunak.

\section{b. Courage (Keberanian)}

Demi tercapainya proyek pengembangan yang sukses, setiap masing-masing anggota tim harus selalu memiliki keberanian, keyakinan serta integritas dalam melakukan tugasnya.

c. Simplicity (Sederhana)

Dengan menggunakan $X P$, artinya tim developer harus tetap melakukan semuanya dengan sederhana, karena salah satu nilai dasar dari XP adalah mencoba untuk selalu mencari solusi yang paling sederhana dan paling praktis.

d. Feedback (Umpan Balik)

Hal ini merupakan salah satu hal penting yang bertujuan untuk mengetahui kemajuan dari proses maupun kualitas perangkat lunak yang dibangun. Dan sudah menjadi kewajiban anggota tim maupun pihak lainnya untuk terlibat dalam memberikan feedback yang baik.

$X P$ memiliki kerangka kerja yang terbagi menjadi empat konteks aktivitas utama. Empat konteks tersebut adalah Planning, Design, Coding dan Testing.

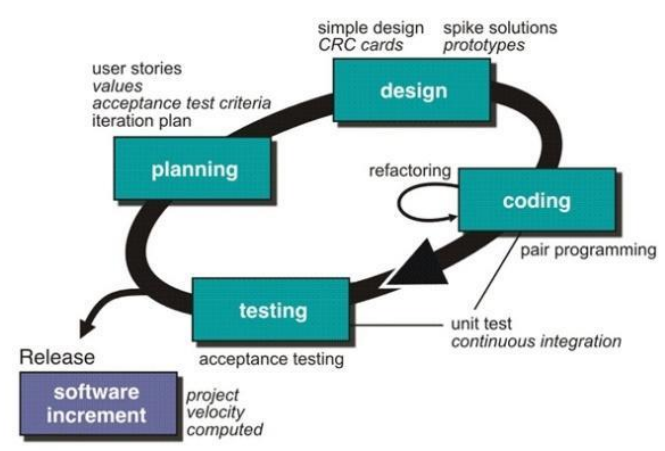

Gambar 2 Kerangka Kerja XP 


\section{a. Planning}

Pada Planning berfokus untuk mendapatkan gambaran fitur dan fungsi dari perangkat lunak yang akan dibangun. Aktivitas planning dimulai dengan membuat kumpulan gambaran atau cerita yang telah diberikan oleh klien yang akan menjadi gambaran dasar dari perangkat lunak tersebut.

\section{b. Design}

Tahap Desain pada model proses XP merupakan panduan dalam membangun perangkat lunak yang didasari dari cerita klien sebelumnya yang telah dikumpulkan pada tahap planning.

\section{c. Coding}

Setelah menyelesaikan gambaran dasar perangkat lunak dan menyelesaikan desain untuk aplikasi secara keseluruhan, XP lebih merekomendasikan tim untuk membuat modul unit test terlebih dahulu yang bertujuan untuk melakukan uji coba setiap cerita dan gambaran yang diberikan oleh klien. Setelah berbagai unit test selesai dibangun, tim barulah melanjutkan aktivitasnya ke penulisan coding aplikasi.

\section{d. Testing}

Walaupun tahapan uji coba sudah dilakukan pada tahapan coding, XP juga akan melakukan pengujian sistem yang sudah sempurna. Pada tahap coding, XP akan terus mengecek dan memperbaiki semua masalah-masalah yang terjadi walaupun hanya masalah kecil.

9. Unified Modelling Language (UML)

UML adalah suatu bahasa yang telah menjadi standar dalam industri untuk visualisasi, merancang dan mendokumentasikan sistem piranti lunak [16]. UML memiliki diagram-diagram seperti Use case diagram merupakan diagram yang menampilkan berbagai peran pengguna dan bagaimana peran ini berfungsi dalam sebuah sistem. Activity diagram merupakan diagram alur kerja yang menjabarkan aktivitas pengguna dan urutannya secara sekuensial. Sequence diagram merupakan diagram yang digunakan untuk menentukan kelas mana yang melakukan kolaborasi dan pesan apa yang masing-masing dari mereka harus kirimkan. Class diagram merupakan diagram yang menunjukkan kelas-kelas objek yang ada pada sistem.

\subsection{Tahapan Penelitian}

Gambar 3 merupakan sistem yang berjalan pada Klinik Risa Rafana di mulai pada proses pendaftaran, pemeriksaan dokter, pemeriksaan penunjang dan pengambilan obat pada apotik yang dilakukan secara manual. 


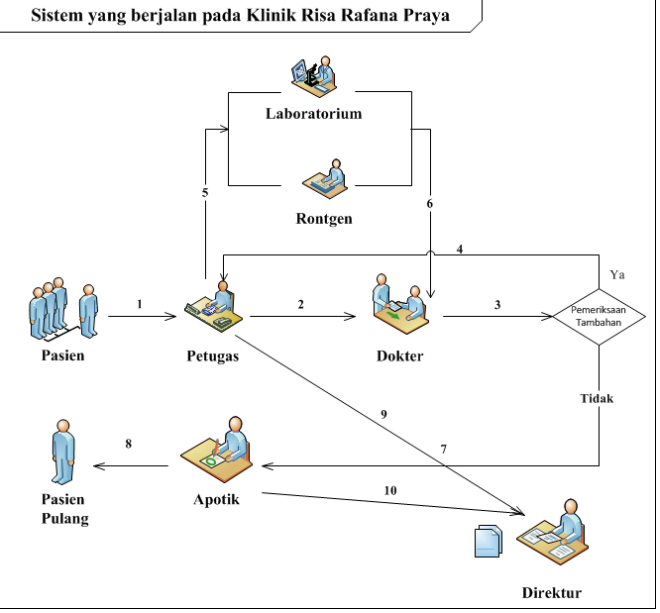

Gambar 3 Sistem yang berjalan

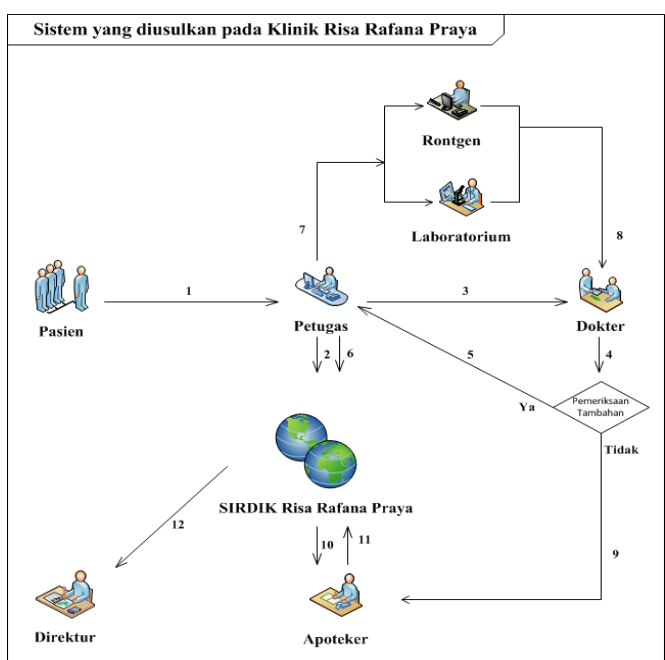

Gambar 4 Sistem yang diusulkan

Gambar 4 merupakan sistem yang diusulkan dalam penelitian ini, dimulai dengan pasien mendaftar pada petugas yang sudah menggunakan komputer untuk menginput data pasien, pasien di periksa oleh dokter, pemeriksaan penunjang baik itu laboratorium maupun rontgen dan dilanjutkan dengan pengambilan obat pada bagian apotik yang telah menggunakan sistem.

\section{Metode Penelitian}

\subsection{Metode Perancangan Sistem}

Berikut di jelaskan tahapan dalam perancangan sistem disajikan dalam tabel 1 berikut: Tabel 1. Metode Perancangan Sistem

\begin{tabular}{|c|c|c|}
\hline \multicolumn{3}{|c|}{ Kegiatan } \\
\hline \multicolumn{3}{|l|}{ Studi Literatur } \\
\hline Input & Proses & Output \\
\hline $\begin{array}{l}\text { Teori } \\
\text { mengenai } \\
\text { sistem } \\
\text { informasi } \\
\text { rekam medik } \\
\text { berbasis web } \\
\text { Teori } \\
\text { mengenai } \\
\text { teknik } \\
\text { pengembanga } \\
\text { n perangkat } \\
\text { lunak } \\
\text { menggunakan } \\
\text { metode XP }\end{array}$ & $\begin{array}{l}\text { Studi Literatur } \\
\text { Melakukan Studi } \\
\text { Literatur dari } \\
\text { berbagai sumber } \\
\text { yang dapat } \\
\text { dipercaya terkait } \\
\text { dengan sistem } \\
\text { informasi rekam } \\
\text { medik berbasis } \\
\text { web dan metode } \\
\text { XP }\end{array}$ & $\begin{array}{l}\text { Pemahaman } \\
\text { teori dan } \\
\text { konsep yang } \\
\text { berkaitan } \\
\text { dengan } \\
\text { pembanguna } \\
\text { n Sistem } \\
\text { Informasi } \\
\text { Rekam Medik } \\
\text { Berbasis Web }\end{array}$ \\
\hline \multicolumn{3}{|l|}{ Palinnig } \\
\hline Input & Proses & Output \\
\hline $\begin{array}{l}\text { Daftar } \\
\text { pertanyaan } \\
\text { yang } \\
\text { digunakan } \\
\text { untuk } \\
\text { mengetahui } \\
\text { kebutuhan apa } \\
\text { saja yang } \\
\text { digunakan } \\
\text { dalam Sistem } \\
\text { Informasi } \\
\text { Rekam Medik } \\
\text { Berbasis Web }\end{array}$ & $\begin{array}{l}\text { Identifikasi } \\
\text { Kebutuhan } \\
\text { Pengguna } \\
\text { Identifikasi } \\
\text { kebutuhan } \\
\text { pengguna dengan } \\
\text { melakukan } \\
\text { wawancara } \\
\text { kepada pihak } \\
\text { Klinik Risa Rafana }\end{array}$ & $\begin{array}{l}\text { Project Kick } \\
\text { Off Meeting } \\
\text { yeng meliputi } \\
\text { User need \& } \\
\text { Stories }\end{array}$ \\
\hline Input & Proses & Output \\
\hline $\begin{array}{l}\text { Project Kick } \\
\text { Off Meeting } \\
\text { yeng meliputi } \\
\text { User need \& } \\
\text { Stories }\end{array}$ & $\begin{array}{l}\text { Analisa } \\
\text { Kebutuhan dan } \\
\text { Perancangan } \\
\text { Sistem } \\
\text { Daftar pertanyaan } \\
\text { yang digunakan } \\
\text { untuk mengetahui } \\
\text { kebutuhan apa } \\
\text { saja yang }\end{array}$ & $\begin{array}{l}\text { System } \\
\text { Requirement } \\
\text { yang meliputi } \\
\text { Use Case } \\
\text { Suite serta } \\
\text { menghasilkan } \\
\text { desain } \\
\text { meliputi, User } \\
\text { Interface. }\end{array}$ \\
\hline
\end{tabular}




\begin{tabular}{|c|c|c|}
\hline & $\begin{array}{l}\text { digunakan pada } \\
\text { sistem informasi } \\
\text { rekam medik } \\
\text { berbasis web }\end{array}$ & \\
\hline \multicolumn{3}{|l|}{ Coding } \\
\hline Input & Proses & Output \\
\hline $\begin{array}{l}\text { System } \\
\text { Requirement } \\
\text { yang meliputi } \\
\text { Use Case } \\
\text { Suite, serta } \\
\text { menghasilkan } \\
\text { desain User } \\
\text { Interface. }\end{array}$ & $\begin{array}{l}\text { Pembangunan } \\
\text { Sistem } \\
\text { Mengimplementas } \\
\text { ikan hasil rencana } \\
\text { ke dalam kode } \\
\text { program }\end{array}$ & $\begin{array}{l}\text { Outputnya } \\
\text { adalah } \\
\text { perangkat } \\
\text { lunak sistem } \\
\text { informasi } \\
\text { rekam medik } \\
\text { berbasis web }\end{array}$ \\
\hline \multicolumn{3}{|l|}{ Testing } \\
\hline Input & Proses & Output \\
\hline $\begin{array}{l}\text { Perangkat } \\
\text { lunak Sistem } \\
\text { informasi } \\
\text { rekam medik } \\
\text { berbasis web }\end{array}$ & $\begin{array}{l}\text { Uji coba sistem } \\
\text { Melakukan uji } \\
\text { coba terhadap } \\
\text { sistem yang telah } \\
\text { dihasilkan }\end{array}$ & $\begin{array}{l}\text { Output yang } \\
\text { dihasilkan } \\
\text { adalah } \\
\text { menemukan } \\
\text { error dan } \\
\text { memperbaikin } \\
\text { ya. }\end{array}$ \\
\hline \multicolumn{3}{|l|}{ Documentation } \\
\hline Input & Proses & Output \\
\hline $\begin{array}{l}\text { Input pada } \\
\text { tahapan ini } \\
\text { adalah seluruh } \\
\text { proses } \\
\text { perancangan } \\
\text { dan } \\
\text { pembangunan } \\
\text { sistem } \\
\text { informasi } \\
\text { rekam medik } \\
\text { berbasis web }\end{array}$ & $\begin{array}{l}\text { Membuat } \\
\text { Laporan } \\
\text { Membuat laporan } \\
\text { mulai dari fase } \\
\text { perencanaan } \\
\text { sampai dengan uji } \\
\text { coba sistem }\end{array}$ & $\begin{array}{l}\text { Outputnya } \\
\text { adalah buku } \\
\text { tugas akhir } \\
\text { dan } \\
\text { dokumentasi } \\
\text { dari } \\
\text { perancangan, } \\
\text { pembanguna } \\
\text { n perangkat } \\
\text { lunak dan uji } \\
\text { coba sistem. }\end{array}$ \\
\hline
\end{tabular}

\section{Wawancara}

Melakukan wawancara langsung dengan pihakpihak terkait yang dilakukan penggalian informasi dengan cara tanya jawab secara langsung kepada pengelola dan staf Klinik Risa Rafana terkait masalah yang dihadapi dalam proses rekam medis pasien.

\subsection{Lokasi Penelitian}

Penelitian dilakukan pada Klinik Risa Rafana yang berlokasi di Wage Desa Batujai Kecamatan Praya Barat Kabupaten Lombok Tengah Provinsi Nusa Tenggara Barat.

\section{Hasil dan Pembahasan}

Sistem Informasi Rekam Medis ini terdiri dari beberapa antarmuka / halaman yang masingmasing memiliki fungsi tersendiri baik untuk menginputkan, menyimpan data maupun melihat laporan. Halaman - halaman yang terdapat dalam sistem adalah sebagai berikut:

\section{Halaman Utama}

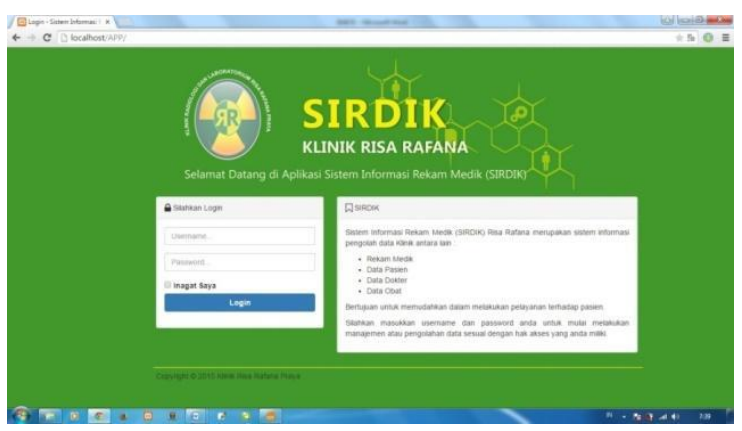

Gambar 5 Halaman Utama

\section{Observasi}

Pengumpulan data yang dilakukan pada saat penelitian dan pencatatan data-data secara langsung pada terhadap Klinik Risa Rafana.

Gambar 1 merupakan halaman yang pertama kali tampil saat membuka sistem yang berisikan form login untuk mengakses sistem rekam medis. Pada halaman ini diminta untuk memasukan username dan 
password, apabila username dan password sudah benar maka akan diarahkan ke halaman Dashboard.

\section{Dashboard}

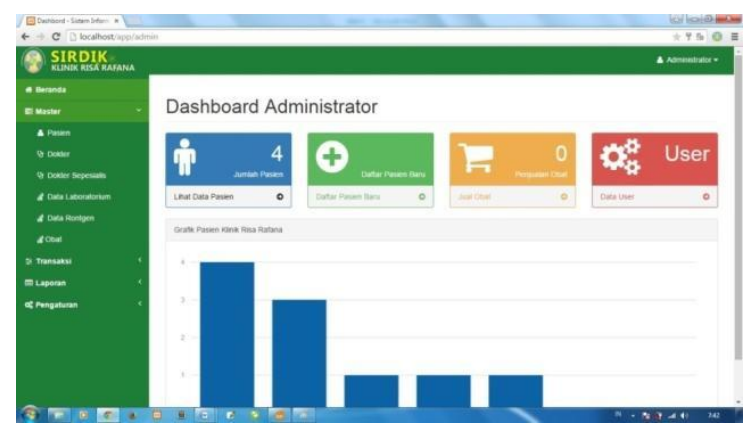

Gambar 6 Dashboard

Gambar 6 merupakah halaman pengolahan data pasien dimana pada sebelah kiri terdapat menu yang terbagi menjadi menu data master, transaksi, laporan dan pengaturan. Terdapat informasi jumlah pasien, jumlah jumlah pasien baru, jumlah transaksi penjualan obat, pengaturan user dan grafik pasien.

3. Antarmuka tambah pasien

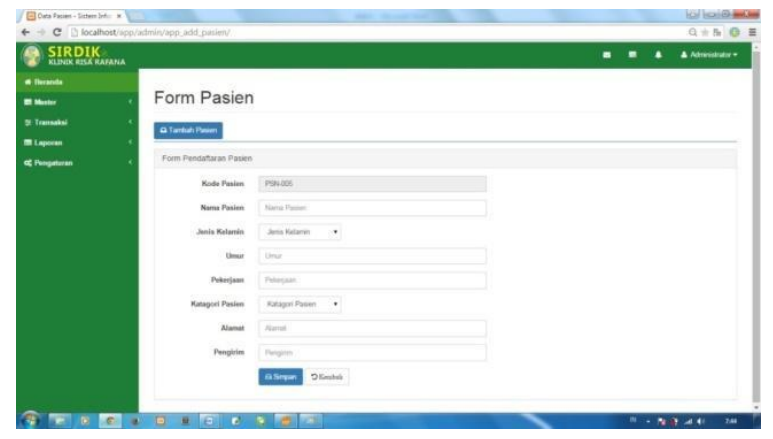

Gambar 7 Halaman tambah pasien

Gambar 7 merupakan form untuk menginputkan data pasien baru yang berkunjung ke Klinik Risa Rafana .

4. Halaman pelayanan yang diberikan kepada pasien

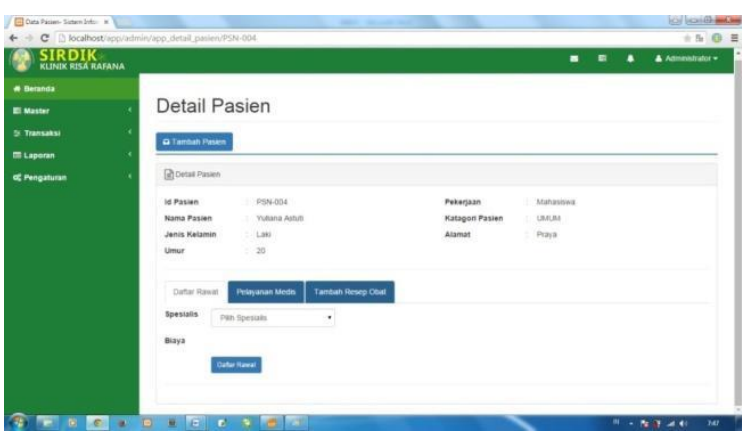

Gambar 8 Halaman pelayanan kepada pasien

Gambar 8 adalah halaman yang berisikan pelayanan kepada pasien yakni perawatan, pemeriksaan laboratorium, rontgen, dan pemberian resep obat.

5. Halaman pemeriksaan pasien rawat

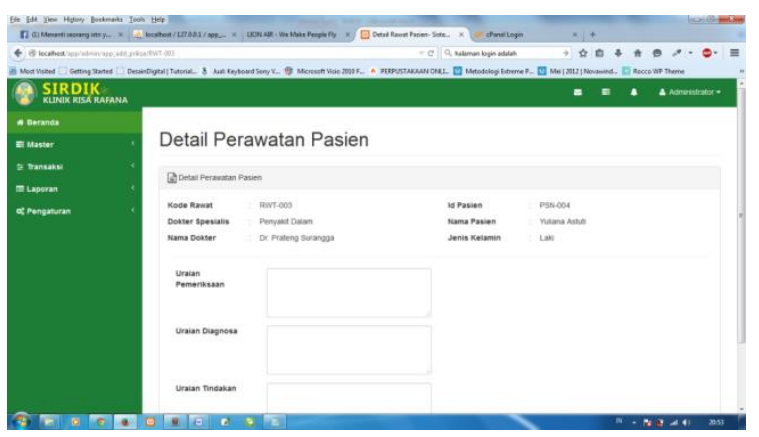

Gambar 9 Halaman pemeriksaan pasien

Gambar 9 adalah halaman pemeriksaan pasien yang berisikan uraian pemeriksaan, uraian diagnosa dan uraian tindakan kepada pasien.

6. Halaman pencarian laporan rawat

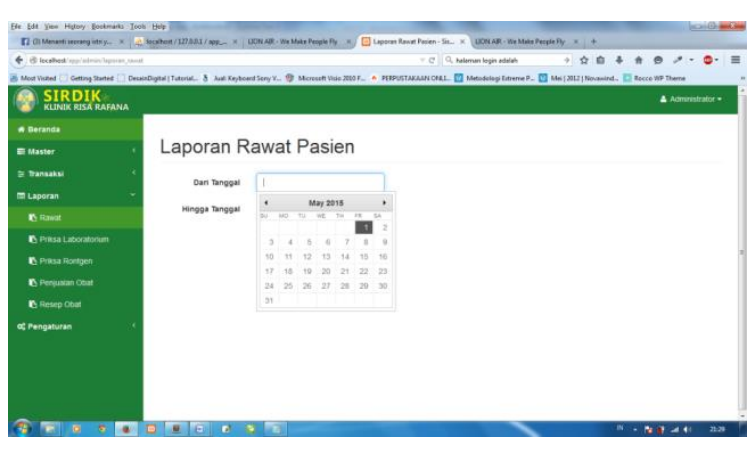

Gambar 10 Halaman laporan rawat

Gambar 10 merupakan halaman untuk melihat laporan perawatan pasien berdasarkan tanggal yang 
inginkan. Dengan memasukkan tanggal awal hingga tanggal akhir laporan.

7. Halaman hasil laporan rawat

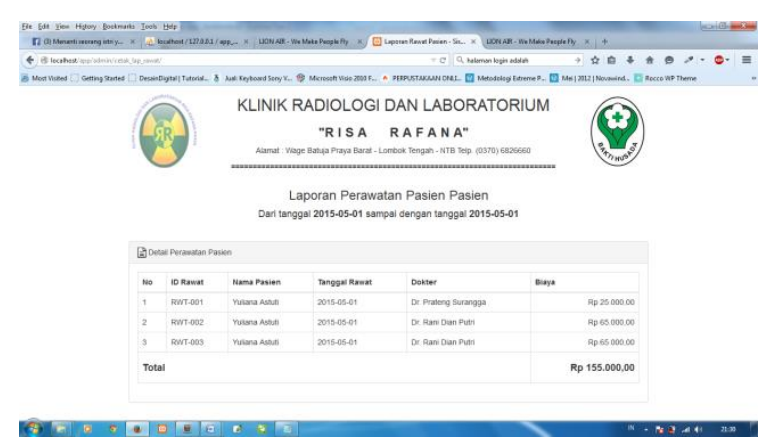

Gambar 11 Halaman hasil laporan rawat

Gambar 11 merupakan hasil pencarian laporan yang siap untuk dicetak.

\section{Kesimpulan}

Berdasarkan kegiatan yang telah dilakukan selama pengembangan Sistem Informasi Rekam Medik Klinik Risa Rafana, maka dapat diambil kesimpulan bahwa perancangan dan pengembangan sistem informasi rekam medik menerapkan metode XP. XP dirasa sangat sesuai, karena dalam penerapannya komunikasi antara pengembang dan client sangat berperan dan metode ini sangat cocok untuk client yang membutuhkan rilis sistem yang cepat serta mengikutsertakan client dalam pengembangan memberikan kepuasan dalam melakukan perubahan sesuai kebutuhan client. Aplikasi sistem Informasi Rekam Medik Klinik Risa Rafana sudah dapat mengelola data pasien, dokter, dokter spesialis, laboratorium, rontgen, obat, sehingga dapat membuat informasi rekam medik dan membuat laporan perawatan pasien, pemeriksaan laboratorium, pemeriksaan rontgen, laporan resep obat, laporan penjualan obat yang telah diberikan pada pasien sehingga memudahkan dalam mendiagnosa penyakit yang diderita oleh pasien. Untuk pengembangan lebih lanjut dapat dilakukan pengembangan modul pembayaran dan diintegrasikan dengan aplikasi BPJS.

\section{Daftar Pustaka}

[1] S. W. Herlambang Brawijaya, Samudi, "Perancangan Sistem Informasi Rekam Medis Berbasis Web Pada Klinik Caritas Bogor (Desktop \& Web Programing)," Indones. J. Netw. Secur., vol. 9, no. 1, pp. 18-25, 2020.

[2] T. Handayani and G. Feoh, "Perancangan Sistem Informasi Rekam Medis Berbasis Web (Studi Kasus Di Klinik Bersalin Sriati Kota Sungai Penuh - Jambi)," J. Teknol. Inf. dan Komput., vol. 2, no. 2, pp. 226-236, 2016, doi: 10.36002/jutik.v2i2.148.

[3] J. S. Pasaribu and J. Sihombing, "Perancangan Sistem Informasi Rekam Medis Pasien Rawat Jalan Berbasis Web Di Klinik Sehat Margasari Bandung," J. IIm. Teknol. Inf. Terap. Vol., vol. III, no. 3, 2017, [Online].

Available: http://jitter.widyatama.ac.id/index.php/jitter/a rticle/view/245/160.

[4] D. Susilo, "Sistem Informasi Rekam Medik Di Poliklinik PT. Air Mancur," vol. 1, no. 1, pp. 58-73, 2010.

[5] Mudmainah, "Aplikasi Sistem Informasi Rumah Sakit Berbasis Web Pada Subsistem Rekam Medis (Studi Kasus: Rumah Sakit Khusus Ibu dan Anak Ummi Khasanah Bantul)," pp. 1-18, 2012.

[6] S. Puspitasari, Y., Purnama, B.E., "Sistem Informasi Rekam Medis Pasien Rawat Jalan dan Observasi Pada Puskemas Pringkuku Kabupaten Pacitan," Indones. J. Netw. 
Secur., pp. 1-6, 2013.

[7] Mentri Kesehatan Republik Indoneisa, "PERATURAN MENTERI KESEHATAN REPUBLIK INDONESIA NOMOR 9 TAHUN 2014," pp. 1-18, 2014.

[8] Depkes, "Manual Rekam Medis - Konsil Kedokteran Indonesia," Buku Man. Rekam Medis, vol. Depkes. (2, p. 23, 2006, [Online]. Available: http://www.kki.go.id/assets/data/menu/Manu al_Rekam_Medis.pdf.

[9] A. Saputra, Trik Kolaborasi Codeigniter dan jQuery. Lokomedia, 2011.

[10] Y. Purbadian, "Framework Codelgnniter 3 Sebuah Panduan dan Best Practice," p. 144, 2016.

[11] J. Meloni, Sams Teach Yourself HTML, CSS, and JavaScript All in One, vol. 21. 2011.

[12] C. Whitehead, Brass Master Class, vol. 6, no. 3. 2013.

[13] N. K. Ningrum, "Global Extreme Prorgamming Framework Untuk Pengembangan Sistem Software Enginering
Dengan Pendekatan Metode Extreme Programming," Maj. IIm. Inform., vol. 3, no. 3, pp. 60-82, 2012.

[14] G. Pearman and J. Goodwill, Extreme Programming. 2006.

[15] A. Fatoni and D. Dwi, "Rancang Bangun Sistem Extreme Programming Sebagai Metodologi Pengembangan Sistem," Prosisko, vol. 3, no. 1, pp. 1-4, 2016, [Online]. Available: http://ejurnal.Ippmunsera.org/index.php/PROSISK O/article/view/116.

[16] S. Dharwiyanti and R. S. Wahono, "Pengantar Unified Modeling LAnguage (UML)," IImuKomputer.com, pp. 1-13, 2003, [Online].

Available: http://www.unej.ac.id/pdf/yanti-uml.pdf.

[17] A. Sudianto, Nurhidayati, and L. Wijaya, Kerta, "Penerapan Sistem Informasi Geografis Untuk Pemetaan Bengkel Tambal Ban di Kecamatan Selong Kabupaten Lombok Timur," Infotek J. Inform. dan Teknol., vol. 3, no. 1, pp. 51-57, 2020. 